\section{Avoidable deaths in the first four years of life among children in the 2004 Pelotas (Brazil) birth cohort study}

\author{
Óbitos evitáveis até os 4 anos de idade na coorte \\ de nascimentos de Pelotas, Rio Grande do Sul, \\ Brasil, 2004
}

\author{
${ }_{1}$ Programa de Pós-graduação \\ em Epidemiologia \\ Universidade Federal de \\ Pelotas, Pelotas, Brasil. \\ 2 Programa de Pós-graduação \\ em Saúde e Comportamento, \\ Universidade Católica de \\ Pelotas, Pelotas, Brasil. \\ 3 Programa de Pós-graduação \\ em Educação Física, \\ Universidade Federal de \\ Pelotas, Pelotas, Brasil. \\ 4 Secretaria de Vigilância em \\ Saúde, Ministério da Saúde, \\ Brasília, Brasil. \\ 5 Universidade Federal de \\ Minas Gerais, Belo Horizonte, \\ Brasil. \\ Correspondence \\ I. S. Santos \\ Programa de Pós-graduação \\ em Epidemiologia \\ Universidade Federal de \\ Pelotas. \\ Rua Marechal Deodoro 1160 \\ 3 o andar, Pelotas, $R S$ \\ 96020-220, Brasil. \\ inasantos@uol.com.br
}

\section{Abstract}

Avoidable deaths have been employed as indicators of health care quality. The aim of this study was to identify factors associated with avoidable deaths from birth to four years of age among children from the 2004 Pelotas (Brazil) birth cohort study. From January 1 ${ }^{\text {st }}$, 2004, to December $31^{\text {st }}$, 2005, deaths were monitored on a daily basis and the causes were investigated and classified according to avoidability. After the first year, deaths were monitored through the Mortality Information System. A total of 94 children died during this period. It was possible to classify 92 deaths, 70 of which were preventable. Low family income, fewer prenatal visits and poor-quality prenatal care, preterm birth, low 5-minute Apgar score, and no breastfeeding in the first 24 hours of life were associated with increased risk of death. Prematurity was present in 39 deaths, but only five of these would have been prevented by measures provided during prenatal care. Although limited, compliance with antenatal care program guidelines is still the most important strategy for preventing avoidable deaths in childhood, particularly among the poorest children.

Neonatal Mortality (Public Health); Infant Mortality; Evaluation
Iná S. Santos 1

Alicia Matijasevich ${ }^{1}$

Aluísio J. D. Barros 1

Elaine P. Albernaz 2

Marlos Rodrigues Domingues 1,3

Neiva C. J. Valle 1

Deborah Carvalho Malta 4,5

Luís Ramón M. R. Gorgot 1

Fernando C. Barros 2

\section{Introduction}

A decrease of two-thirds in the mortality rate in children under five years of age is one of the millennium development goals signed in 2000 by Brazil and the other United Nations member states ${ }^{1}$. The under-five mortality rate, which was 57 per thousand live births in Brazil in 1990, decreased substantially in the followingyears, reaching 20 per thousand live births in 2005, thus close to the 19 per thousand live births established as the goal for 20152 . This reduction resulted from a series of social and health care improvements for mothers and children during the same period, such as oral rehydration therapy for diarrhea, the immunization program, promotion of breastfeeding, and expansion of primary care, among others, with their main impact on the causes of post-neonatal infant deaths. The neonatal period currently concentrates the largest share of deaths in children under five in Brazil 3.

Although Brazil is close to achieving the quantitative goal, the number of deaths under one year of age is still inconsistent with the country's economic potential 4 . In addition, many of these deaths are due to avoidable causes 5 , since they are amenable to prevention with available interventions. Taking death as one of the extreme results of quality of care, the proportion of avoidable deaths has been used as an indicator of quality of the health system $6,7,8,9$ and its occurrence has been interpreted as a sign of flaws to 
be corrected in two other dimensions of quality of care (in the supply - organization and inputs - and in the health care process) ${ }^{10}$. Equity in access to services with adequate quality is one of the principal health care quality indicators 10 .

The aim of the current study was to identify factors associated with increased risk of dying from avoidable causes in the first four years of life among children in the 2004 Pelotas birth cohort study. Identification of these causes aims to help public health managers make evidence-based decisions for the prevention of early childhood mortality.

\section{Material and methods}

The birth cohort study launched in Pelotas, Rio Grande do Sul State, Brazil, in 2004 was planned to include all the children born to mothers living in the urban area of the city and in the neighborhood of Jardim América, which was incorporated into the neighboring city of Capão do Leão in May 1982 (it was maintained in order to ensure comparability with the two previous birth cohorts, 1982 and 1993, underway in Pelotas).

From January 1 to December 31, 2004, all the hospitals were visited daily by trained teams. The mothers were interviewed shortly after giving birth (perinatal study). The interview used a precoded questionnaire for gathering information on the mother, family, and child. Home visits have been made to all the children in the cohort at 3 , 12,24 , and 48 months of age, with data collected on health, diet, care, and use of health services, among others. More details on the methodology used in the 2004 cohort are available in a previous publication 11 .

Deaths during the first year of life were investigated in a sub-study conducted from January 1 , 2004, to December 31, 2005, when the last child born in 2004 reached one year of age. Deaths were monitored through daily contacts with the main hospitals in the city, with visits to intensive care units (ICUs), nurseries, pediatric wards, and emergency services. In order to detect out-ofhospital deaths, the notary publics, cemeteries, and Regional Health Office were also visited. In the case of hospitalized children, a systematic review was done of the patient chart, where information was recorded on the reason for hospitalization, history and evolution of the illness, lab and imaging tests, treatment, and diagnosis. When necessary, data from the perinatal interview with the mother were also used.

For children that died between seven and 364 days of life, a home interview was held with the mother, investigating the clinical history of the illness and its antecedents. For this interview, the questionnaires used in the Inter-American Investigation of Mortality in Childhood 12 were adapted to the local reality in Pelotas. For deaths that occurred out-of-hospital or in other cities, the information was gathered from death certificates and completed with home interviews with family members.

Two independent pediatricians were responsible for determining the underlying cause of death by means of a careful review of all the available information. In case of disagreement, a third pediatrician was invited to discuss the case to reach a final decision. The underlying cause of death was coded according to the International Classification of Diseases (ICD-10) 13. As part of the investigation, based on the records and reports by family members, the reviewers also attempted to identify possible flaws in the preventive and curative services that might have contributed to the child's death. Such flaws included difficulty by the pregnant woman in accessing the clinic or maternity hospital, transportation of the newborn to the neonatal ICU in an unheated incubator, and lack of priority in the health services for newborns and symptomatic infants, among others.

For children that died after the first year of life or that had not been located in the follow-up visits to the cohort, a cause of death was obtained by analyzing the database from the Mortality Information System (SIM) for the Rio Grande do Sul State and the city of Pelotas, where mother's name and child's date of birth were compared to those available in the cohort's perinatal databank.

The maternal independent variables obtained from the interviews conducted in the perinatal period and used in this study included the following types of characteristics: socioeconomic (family income, schooling, and marital status); biological/demographic (age, pregestational body mass index, height, and skin color); behavior/mental health (smoking during the pregnancy, planned pregnancy, and history of depression or "nervous problems" during the pregnancy); childbearing (parity, presence of other children in the home, prior stillbirth); healthcare (place where prenatal care was performed, gestational age at the beginning of prenatal care, and number of prenatal visits); tests and procedures during prenatal care (obstetric ultrasound and tetanus vaccination - women whose tetanus vaccination status was up-to-date were classified as having been vaccinated during the current pregnancy); history of illness during the pregnancy (anemia, arterial hypertension, diabetes mellitus, and urinary tract infection); 
and delivery (type, financing, attending health professional, and presence of pediatrician in the delivery room). The following data were collected on the child at birth: sex, weight, gestational age, neonatal complications (e.g., hypoglycemia, seizures, transient tachypnea, hypothermia, cardiac abnormality or disorder, low birth weight, prematurity, and aspiration syndrome, among others), admission to neonatal ICU, breastfeeding in the first 24 hours, and 1 and 5-minute Apgar score. Gestational age was defined according to an algorithm 14 in which the estimated gestational age based on the date of last menstrual period was adopted whenever available and consistent with the birth weight, length, and head circumference, using normal curves for these parameters for each week of gestational age 15 . When gestational age based on the date of last menstrual period was unknown or inconsistent, the study adopted the clinical estimate of maturity according to Dubowitz et al. 16, performed in all the newborns. Births at less than 37 weeks of gestation were classified as preterm. Newborns were subsequently categorized as small, large, or appropriate for gestational age according to the curve by Williams et al. 17. Newborns were only classified as small for gestational age when they were below the $10^{\text {th }}$ percentile of weight for gestational age and sex; large for gestational age were those above the $90^{\text {th }}$ percentile; and the rest were appropriate for gestational age.

The dependent variable, avoidable deaths, was constructed using the list of causes proposed by Malta et al. 18, in which the causes of death are divided into three groups: avoidable deaths, deaths from ill-defined causes, and other causes. Avoidable causes include four groups: preventable by immunization; reducible by adequate care for the mother during pregnancy and childbirth and for the newborn; reducible through adequate diagnosis and treatment; and reducible through adequate health promotion measures, combined with adequate health care.

Children less than one year of age that died at home without apparent cause (the mother found the child dead in the cradle, without identification of any previous symptoms) and that were submitted to autopsy, where the report specified "death by aspiration of milk" or "death by suffocation", or those that did not undergo autopsy and were considered ICD cause unknown, were classified as cases of sudden infant death syndrome (SIDS). Although the list by Malta et al. 18 classifies SIDS among "other causes", the current study included it among deaths reducible by adequate health promotion measures, since the recommendation of dorsal decubitus (supine) as the adequate position for the child's sleep is known to be effective as a preventive measure 19 . When prematurity was present among the causes leading to death, it was classified as the underlying cause unless there was an associated condition in the newborn like congenital syphilis or malformation.

In the analyses, the risk of dying from avoidable causes was calculated by comparing the family, maternal, health care utilization, and child's own characteristics for children that died of avoidable causes and those that survived until 2008. The crude and adjusted associations between the variables were calculated by Poisson regression with robust variance 20 . The adjusted analysis was performed according to a hierarchical analytical model (Figure 1), constructed in three levels ( 1 st level: family income; $2^{\text {nd }}$ level: maternal and prenatal characteristics; and $3^{\text {rd }}$ level: characteristics of the delivery and of the child at birth). Variables with high colinearity were excluded from the analysis. Variables associated with avoidable death with $\mathrm{p}$-value $\leq 0.20$ were maintained in the adjusted analysis for adjustment of the others. Data entry and analysis used Epi Info 6.04 (Centers for Disease Control and Prevention, Atlanta, USA) and Intercooled Stata 11.0 (Stata Corp., College Station, USA).

The perinatal study and each follow-up of the 2004 cohort were approved by the Ethics Research Committee of the School of Medicine of the Pelotas Federal University (Faculdade de Medicina, Universidade Federal de Pelotas). Informed consent was obtained in writing from the mothers before the data collection.

\section{Results}

Among the 4,231 live births in Pelotas in the year 2004, 94 deaths occurred by 2008, when all the children had reached four years of age. Most of the deaths (82) occurred in the first year of life. Only two deaths could not be evaluated because there was no information on cause of death. The other 92 were classified according to the list by Malta et al. 18; of these, 70 were avoidable, of which the majority (65) occurred in the first year of life. Some two-thirds of avoidable deaths occurred in the neonatal period (31 in the first week and 14 in the late neonatal period). The majority of avoidable deaths would have been reducible by adequate prenatal care for the mother $(n=41)$. Prematurity was present in 39 of the deaths in the first year, and of these, there was reference to neonatal respiratory distress syndrome in 28 infants. Sudden death was identified as the cause of death in four children and congenital syphilis in two. 


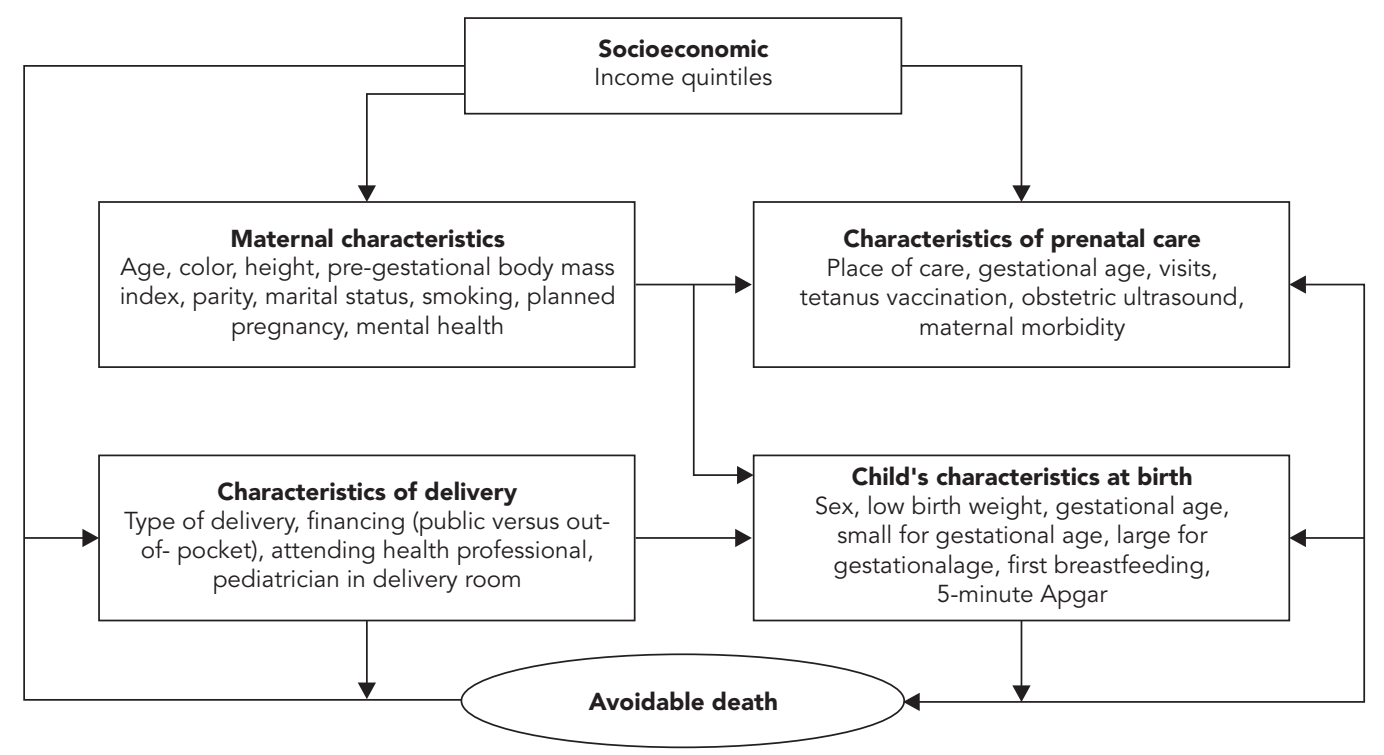

Among the 10 deaths from known causes between 12 and 48 months of age, two would have been preventable by adequate diagnosis and treatment (bronchopneumonia and acute myocarditis) and two by adequate health promotion actions (both due to traffic accidents).

Table 1 shows the incidence of avoidable deaths and the cumulative incidence ratio according to the child's characteristics at birth. The occurrence of avoidable deaths was similar between the two sexes (1.6\% in girls and $1.7 \%$ in boys). The incidence of deaths was significantly higher among children with low birth weight $(<2,500 \mathrm{~g})$ and preterm birth $(<37$ weeks gestational age). The risk was also higher among those with a history of neonatal complications, for those that did not begin breastfeeding in the first 24 hours of life, and for those with 5-minute Apgar less than 7.

The risk of dying from avoidable causes was higher among children of mothers with low family income, black skin color, single or without a partner, and low schooling (Table 2). Among children of mothers that smoked or reported depression or nervous problems during the pregnancy, the incidence of avoidable deaths was practically double than controls.

As for variables related to pregnancy and prenatal and delivery characteristics (Table 3), there was an increased risk of avoidable death among children of mothers with fewer than six prenatal visits, who had not performed an obstetric ultrasound examination, and who failed to receive tetanus vaccination. Among the maternal diseases, only diabetes mellitus increased the risk of avoidable death, which was 2.5 times greater than among children of mothers without diabetes. A similar size risk was observed among children of mothers whose delivery was covered under the Brazilian Unified National Health System (SUS).

In the adjusted analysis (Table 4), among the family, maternal, and health services utilization characteristics, risk factors that remained associated with avoidable deaths were low family income, fewer prenatal visits, not having received tetanus vaccination, and diabetes mellitus during the pregnancy. Among the child's variables, the risk factors that remained associated with avoidable deaths were lower gestational age at birth, not having breastfed in the first 24 hours of life, and 5-minute Apgar less than 7.

The risk of dying from avoidable causes increased proportionally with low family income and low gestational age at birth. Children born to families in the poorest quintile showed a threefold risk of dying from an avoidable cause as compared to those born to families from the wealthi- 
Incidence of avoidable deaths among live births from the 2004 cohort according to child's characteristics at birth (N = 4,207).

\begin{tabular}{|c|c|c|c|c|}
\hline Variable & $\mathrm{n}$ & Incidence (\%) & $\begin{array}{l}\text { Cumulative incidence } \\
\text { ratio }(95 \% \mathrm{Cl})\end{array}$ & p-value * \\
\hline Sex & & & & 0.7 \\
\hline Female & 2,028 & $32(1.6)$ & 1.00 & \\
\hline Male & 2,179 & $38(1.7)$ & $1.11(0.70-1.76)$ & \\
\hline Low birth weight ** & & & & $<0.001$ \\
\hline No & 3,791 & $28(0.7)$ & 1.00 & \\
\hline Yes & 414 & $41(9.9)$ & $13.41(8.38-21.45)$ & \\
\hline Gestational age in weeks & & & & $<0.001 * * *$ \\
\hline $22-33$ & 138 & $32(23.2)$ & $33.29(20.30-54.60)$ & \\
\hline $34-36$ & 468 & $7(1.5)$ & $2.15(0.93-4.94)$ & \\
\hline$\geq 37$ & 3,589 & $25(0.7)$ & 1.00 & \\
\hline Small for gestational age & & & & 0.7 \\
\hline No & 3,677 & $57(1.6)$ & 1.00 & \\
\hline Yes & 519 & $7(1.4)$ & $0.87(0.40-1.90)$ & \\
\hline Large for gestational age & & & & 0.5 \\
\hline No & 3,897 & $58(1.5)$ & 1.00 & \\
\hline Yes & 299 & $6(2.0)$ & $1.35(0.59-3.10)$ & \\
\hline Neonatal complications & & & & $<0.001$ \\
\hline No & 3,676 & $25(0.7)$ & 1.00 & \\
\hline Yes & 516 & $41(8.0)$ & $11.68(7.17-19.05)$ & \\
\hline Began breastfeeding in first 24 hours & & & & $<0.001$ \\
\hline Yes & 3,656 & $22(0.6)$ & 1.00 & \\
\hline No & 489 & $41(8.4)$ & $13.93(8.37-23.19)$ & \\
\hline 5-minute Apgar & & & & $<0.001$ \\
\hline$<7$ & 86 & $17(19.8)$ & $16.52(9.93-27.46)$ & \\
\hline$\geq 7$ & 4,095 & $49(1.2)$ & 1.00 & \\
\hline
\end{tabular}

95\% $\mathrm{Cl}: 95 \%$ confidence interval.

* Poisson with robust variance;

** $<2,500$ grams;

$\star \star \star$ Poisson with robust variance for linear trend.

est quintile. Among children whose mothers had fewer than six prenatal visits, the risk of dying was 5.6 times greater than among children of mothers with six or more visits during the pregnancy. Not receiving tetanus vaccination involved an $85 \%$ greater risk, and diabetes mellitus was associated a risk 3.5 times higher.

The effect of family income on risk of dying from an avoidable cause was attenuated by the number of prenatal visits. When the analysis was adjusted for mother's skin color, depression/ nervous problems in the pregnancy, and month of the pregnancy at the first prenatal visit, the number of prenatal visits captured $24 \%$ of the effect of income, the relative risk of which decreased from 1.32 to 1.01 . Inclusion of the thirdlevel variables (gestational age at birth, breast- feeding in the first 24 hours of life, and 5-minute Apgar) brought no further reductions in the effect of income. The interaction test between family income and number of prenatal visits was not statistically significant. Since fewer prenatal visits can result from preterm birth (rather than cause it), we compared the number of prenatal visits only among women with term deliveries (37-41 weeks gestation): mothers from the poorest quintile had a mean of 7.27 visits, while those from the wealthiest quintile had a mean of 10.32 visits $(\mathrm{p}<0.001)$.

Among children born at less than 34 weeks gestational age, the risk of dying from an avoidable cause was seven times greater than among those born at term. The risks among children that were not breastfed in the first 24 hours of life 
Incidence of avoidable death among live births from the 2004 cohort according to socioeconomic variables and maternal characteristics ( $\mathrm{N}=4,207)$

\begin{tabular}{|c|c|c|c|c|}
\hline Variable & $\mathrm{n}$ & Incidence (\%) & $\begin{array}{l}\text { Cumulative incidence } \\
\text { ratio }(95 \% \mathrm{Cl})\end{array}$ & p-value * \\
\hline Income quintiles & & & & 0.002 ** \\
\hline 1 & 866 & $22(2.5)$ & $3.00(1.29-6.99)$ & \\
\hline 2 & 851 & $20(2.4)$ & $2.78(1.18-6.53)$ & \\
\hline 3 & 809 & $10(1.2)$ & $1.46(0.56-3.82)$ & \\
\hline 4 & 854 & $11(1.3)$ & $1.52(0.59-3.91)$ & \\
\hline 5 & 827 & $7(0.9)$ & 1.00 & \\
\hline Mother's age (years) & & & & $0.2^{\star \star}$ \\
\hline$<20$ & 793 & $16(2.0)$ & 1.00 & \\
\hline $20-34$ & 2,856 & $48(1.7)$ & $1.00(1.00-1.01)$ & \\
\hline$\geq 35$ & 556 & $6(1.1)$ & $1.00(1.00-1.01)$ & \\
\hline Mother's skin color & & & & 0.003 \\
\hline White or other & 3,366 & $46(1.4)$ & 1.00 & \\
\hline Black & 841 & $24(2.9)$ & $2.09(1.28-3.40)$ & \\
\hline Mother's height $(\mathrm{cm})$ & & & & 0.6 \\
\hline$<150$ & 124 & $1(0.8)$ & 1.00 & \\
\hline$\geq 150$ & 2,878 & $40(1.4)$ & $1.72(0.24-12.44)$ & \\
\hline Pre-gestational body mass index $\left(\mathrm{kg} / \mathrm{m}^{2}\right)$ & & & & 0.6 \\
\hline$\leq 18.4$ & 214 & $2(0.9)$ & 1.00 & \\
\hline $18.5-24.9$ & 1,818 & $21(1.2)$ & $1.24(0.29-5.24)$ & \\
\hline $25.0-29.9$ & 587 & $11(1.9)$ & $2.01(0.45-8.98)$ & \\
\hline$\geq 30.0$ & 259 & $3(1.2)$ & $1.24(0.21-7.35)$ & \\
\hline Parity & & & & $0.06 * *$ \\
\hline 1 & 1,656 & $23(1.4)$ & 1.00 & \\
\hline 2 & 1,108 & $15(1.4)$ & $0.97(0.51-1.86)$ & \\
\hline 3 & 676 & $14(2.1)$ & $1.49(0.77-2.88)$ & \\
\hline$\geq 4$ & 766 & $18(2.4)$ & $1.69(0.92-3.12)$ & \\
\hline Marital status & & & & 0.0008 \\
\hline Married/With partner & 3,520 & $48(1.4)$ & 1.00 & \\
\hline Without a partner & 687 & $22(3.2)$ & $2.35(1.43-3.86)$ & \\
\hline Mother's schooling (years) & & & & $0.002 * \star$ \\
\hline$<4$ & 345 & $11(3.2)$ & $3.01(1.45-6.27)$ & \\
\hline $4-8$ & 2,027 & $39(1.9)$ & $1.82(1.05-3.13)$ & \\
\hline$\geq 9$ & 1,794 & $19(1.1)$ & 1.00 & \\
\hline Other children in home & & & & $0.5^{\star \star}$ \\
\hline 0 & 1,965 & $30(1.5)$ & 1.00 & \\
\hline 1 or 2 & 1,780 & $31(1.7)$ & $1.14(0.69-1.88)$ & \\
\hline$\geq 3$ & 462 & $9(2.0)$ & $1.28(0.61-2.67)$ & \\
\hline Primiparous & & & & 0.3 \\
\hline Yes & 1,656 & $23(1.4)$ & 1.00 & \\
\hline No & 2,550 & $47(1.8)$ & $1.33(0.81-2.18)$ & \\
\hline Smoking during the pregnancy & & & & 0.009 \\
\hline No & 3,053 & $41(1.3)$ & 1.00 & \\
\hline Yes & 1,155 & $29(2.5)$ & $1.87(1.17-3.00)$ & \\
\hline Planned pregnancy & & & & 0.2 \\
\hline No & 2,377 & $45(1.9)$ & $1.39(0.85-2.25)$ & \\
\hline Yes & 1,829 & $25(1.4)$ & 1.00 & \\
\hline
\end{tabular}

(continues) 
Table 2 (continued)

\begin{tabular}{lccc}
\hline Variable & $\mathbf{n}$ & Incidence (\%) & $\begin{array}{c}\text { Cumulative incidence } \\
\text { ratio }(95 \% \mathrm{Cl})\end{array}$ \\
\hline $\begin{array}{l}\text { Depression/nervous problems in } \\
\text { the pregnancy }\end{array}$ & & & \\
No & 3,152 & $42(1.3)$ & 1.00 \\
Yes & 1,053 & $28(2.7)$ & $2.00(1.24-3.20)$ \\
\hline
\end{tabular}

95\% Cl: 95\% confidence interval.

* Poisson with robust variance;

** Poisson with robust variance for linear trend.

Table 3

Incidence of avoidable deaths among live births from the 2004 cohort according to prenatal and delivery variables $(N=4,207)$.

\begin{tabular}{|c|c|c|c|c|}
\hline Variable & $\mathrm{n}$ & Incidence (\%) & $\begin{array}{c}\text { Cumulative incidence } \\
\text { ratio }(95 \% \mathrm{Cl})\end{array}$ & p-value * \\
\hline Prenatal care in public health system & & & & 0.6 \\
\hline No & 2,313 & $32(1.4)$ & 1.00 & \\
\hline Yes & 1,823 & $29(1.6)$ & $1.15(0.70-1.89)$ & \\
\hline Beginning of prenatal care & & & & 0.2 \\
\hline 1st to $5^{\text {th }}$ month & 3,783 & $53(1.4)$ & 1.00 & \\
\hline 6th to 9 th month & 284 & $7(2.5)$ & $1.76(0.81-3.83)$ & \\
\hline Prenatal visits & & & & $<0.001$ \\
\hline$\geq 6$ & 3,265 & $25(0.8)$ & 1.00 & \\
\hline$<6$ & 764 & $41(5.4)$ & $7.01(4.29-11.45)$ & \\
\hline Tetanus vaccination in pregnancy & & & & 0.002 \\
\hline No & 973 & $25(2.6)$ & $2.23(1.35-3.70)$ & \\
\hline Yes & 3,129 & $35(1.2)$ & 1.00 & \\
\hline Ultrasound in pregnancy & & & & $<0.001$ \\
\hline Yes & 4,073 & $59(1.5)$ & 1.00 & \\
\hline No & 134 & $11(8.2)$ & $5.67(3.05-10.54)$ & \\
\hline Anemia in pregnancy & & & & 0.06 \\
\hline No & 1,401 & $30(2.1)$ & $1.56(0.97-2.51)$ & \\
\hline Yes & 2,775 & $38(1.4)$ & 1.00 & \\
\hline High blood pressure in pregnancy & & & & 0.3 \\
\hline No & 3,200 & $50(1.6)$ & 1.00 & \\
\hline Yes & 999 & $20(2.0)$ & $1.28(0.77-2.14)$ & \\
\hline Diabetes in pregnancy & & & & 0.04 \\
\hline No & 4,079 & $65(1.6)$ & 1.00 & \\
\hline Yes & 125 & $5(4.0)$ & $2.51(1.03-6.13)$ & \\
\hline Urinary infection in pregnancy & & & & 0.3 \\
\hline No & 2,637 & $39(1.5)$ & 1.00 & \\
\hline Yes & 1,556 & $30(1.9)$ & $1.30(0.81-2.09)$ & \\
\hline Type of delivery & & & & 0.3 \\
\hline Vaginal & 2,301 & $43(1.9)$ & $1.32(0.82-2.13)$ & \\
\hline Cesarean & 1,906 & $27(1.4)$ & 1.00 & \\
\hline
\end{tabular}

(continues) 
Table 3 (continued)

\begin{tabular}{|c|c|c|c|c|}
\hline Variable & $\mathbf{n}$ & Incidence (\%) & $\begin{array}{c}\text { Cumulative incidence } \\
\text { ratio }(95 \% \mathrm{Cl})\end{array}$ & $\mathrm{p}$-value * \\
\hline Delivery in SUS & & & & 0.03 \\
\hline No & 794 & $6(0.8)$ & 1.00 & \\
\hline Yes & 3,408 & $64(1.9)$ & $2.49(1.08-5.72)$ & \\
\hline Attending professional in delivery & & & & 0.3 \\
\hline Physician & 3,733 & $60(1.6)$ & 1.00 & \\
\hline Other & 449 & $10(2.2)$ & $1.39(0.71-2.69)$ & \\
\hline Pediatrician in delivery room & & & & 1.0 \\
\hline No & 745 & $10(1.3)$ & $1.00(0.55-2.01)$ & \\
\hline Yes & 2,688 & $36(1.3)$ & 1.00 & \\
\hline
\end{tabular}

95\% Cl: 95\% confidence interval; SUS: Brazilian Unified National Health System.

* Poisson with robust variance.

Table 4

Incidence of avoidable deaths among live births from the 2004 cohort according to independent variables $(N=4,207)$.

\begin{tabular}{|c|c|c|c|c|c|}
\hline Variable & Level & $\begin{array}{l}\text { Crude cumulative incidence } \\
\text { rate }(95 \% \mathrm{Cl})\end{array}$ & $\mathrm{p}$-value * & $\begin{array}{l}\text { Adjusted cumulative incidence } \\
\text { rate }(95 \% \mathrm{Cl})\end{array}$ & p-value * \\
\hline Income quintiles & & & $0.001 * \star$ & & $0.001 \star \star$ \\
\hline 1 & 1 st & $3.00(1.29-6.99)$ & & $3.00(1.29-6.99)$ & \\
\hline 2 & & $2.78(1.18-6.53)$ & & $2.78(1.18-6.53)$ & \\
\hline 3 & & $1.46(0.56-3.82)$ & & $1.46(0.56-3.82)$ & \\
\hline 4 & & $1.52(0.59-3.91)$ & & $1.52(0.59-3.91)$ & \\
\hline 5 & & 1.00 & & 1.00 & \\
\hline Mother's skin color & 2nd & & 0.003 & & 0.09 \\
\hline White or other & & 1.00 & & 1.00 & \\
\hline Black & & $2.09(1.28-3.40)$ & & $1.62(0.94-2.79)$ & \\
\hline Depression/"nervous problem" & $2^{\text {nd }}$ & & 0.004 & & 0.05 \\
\hline \multicolumn{6}{|l|}{ in pregnancy } \\
\hline No & & 1.00 & & 1.00 & \\
\hline Yes & & $2.00(1.24-3.20)$ & & $1.67(1.00-2.78)$ & \\
\hline Beginning of prenatal care & 2nd & & 0.2 & & 0.2 \\
\hline 1 st to $5^{\text {th }}$ month & & 1.00 & & 1.00 & \\
\hline 6th to 9th month & & $1.76(0.81-3.83)$ & & $0.55(0.24-1.26)$ & \\
\hline Prenatal visits & 2nd & & $<0.001$ & & $<0.001$ \\
\hline$\geq 6$ & & 1.00 & & 1.00 & \\
\hline$<6$ & & $7.01(4.29-11.45)$ & & $5.62(3.05-10.36)$ & \\
\hline Tetanus vaccination in pregnancy & $2^{\text {nd }}$ & & 0.002 & & 0.02 \\
\hline No & & $2.23(1.35-3.70)$ & & $1.85(1.11-3.08)$ & \\
\hline Yes & & 1.00 & & 1.00 & \\
\hline Diabetes in pregnancy & 2 nd & & 0.04 & & 0.002 \\
\hline No & & 1.00 & & 1.00 & \\
\hline Yes & & $2.51(1.03-6.13)$ & & $3.55(1.60-7.88)$ & \\
\hline Gestational age (weeks) & 3 rd & & $<0.001 * \star$ & & $<0.001$ ** \\
\hline $22-33$ & & $33.29(20.30-54.60)$ & & $7.07(3.53-14.16)$ & \\
\hline $34-36$ & & $2.15(0.93-4.94)$ & & $0.96(0.41-2.26)$ & \\
\hline$\geq 37$ & & 1.00 & & 1.00 & \\
\hline
\end{tabular}

(continues) 


\begin{tabular}{lcccc}
\hline Variable & Level & $\begin{array}{c}\text { Crude cumulative incidence } \\
\text { rate }(95 \% \mathrm{Cl})\end{array}$ & $\mathrm{p}$-value * & $\begin{array}{c}\text { Adjusted cumulative incidence } \\
\text { rate }(95 \% \mathrm{Cl})\end{array}$ \\
\hline $\begin{array}{l}\text { Began breastfeeding in first } 24 \text { hours } \\
\text { No }\end{array}$ & 3rd & & $<0.001$ & $3.08(1.65-5.75)$ \\
$\quad$ Yes & & $13.93(8.37-23.19)$ & & 1.00 \\
$\begin{array}{l}5-\text { minute Apgar } \\
<7\end{array}$ & 3rd & 1.00 & $<0.001$ & $2.48(1.27-4.84)$ \\
$\geq 7$ & & $16.52(9.93-27.46)$ & 1.00 & 0.008 \\
\hline
\end{tabular}

95\% Cl: 95\% confidence interval.

* Poisson with robust variance;

** Poisson with robust variance for linear trend.

and those with 5-minute Apgar $<7$ were 3 and 2.5 times greater, respectively.

Mother's skin color, smoking, depression/ nervous problems during the pregnancy, and delivery under the SUS lost their statistical significance in the adjusted analysis. The variables low birth weight, neonatal complications, marital status, maternal schooling, and prenatal ultrasound, which were significant in the crude analysis, lost significance in the adjusted analysis, with $\mathrm{p}>0.20$, and were thus not maintained in the multivariate model.

\section{Discussion}

The most relevant findings from the current study were that for every four deaths that occurred in the first four years of life among children from the 2004 cohort, three could have been avoided, and that family income, number of prenatal visits, and gestational age at birth were the principal determinants. The principal factor involved in the occurrence of avoidable deaths was prematurity, present in more than half of the deaths in the first year of life.

The study identified 70 deaths that were considered avoidable, or some $76 \%$ of the deaths, and this rate thus became an important parameter for monitoring trends in coming years and for helping to plan measures for their reduction. The current study also helped to validate the list of avoidable deaths by Malta et al. 16, for example by proposing the change in the classification of cases of sudden infant death syndrome to include it under avoidable deaths based on health promotion measures. In addition, it allows comparing the distribution of causes of death obtained from a secondary database (SIM) with those investigated in home visits and health services. In this case, for Brazil as a whole, deaths classified as avoidable account for $68 \%$ of the events, as compared to $76 \%$ in Pelotas. The difference in the proportion may be due to the revision of causes of deaths through the investigations described in the current study, upgrading the records and decreasing the proportion of ill-defined causes. Another reason is the increase in the proportion of detection of deaths due to prematurity ( $42 \%$ of the deaths in the current study and $24 \%$ in Brazil as a whole), when the deaths in the SIM database are analyzed 3 . The higher number of missing values and lower quality of information on gestational age in the official SIM data, as compared to databases in primary studies, are possible causes of these differences.

Some conceptual issues in the current study need discussion, as it was an evaluation of the local health system. Various health determinants are not linked directly to quality of health care, but rather to other areas of society such as traffic safety 21 . However, in the case of prematurity, the known preventive measures belong to the health sector per se and should be implemented during prenatal care 22 .

Furthermore, what is considered preventable through health care can vary over time, to the extent that new treatments and strategies are developed 23 . In addition, within a given time frame, what is considered preventable through health care may vary as a function of the context in which the care is provided 24 . The strong association observed in this study between low family income, corroborating other studies 6,7,8,25,26,27, clearly illustrates how socioeconomic status determines inequalities in access to (and quality of) services received. In this study, the causal network connecting socioeconomic iniquity to risk of dying begins with the poorest pregnant women having less access to prenatal care (the mean number of prenatal visits was 7 for the poorest women and 10 for the wealthiest) 28 , followed by 
low-quality prenatal care (as revealed by studies planned specifically to assess prenatal care in the city) $28,29,30$, resulting in a higher preterm delivery rate $(21 \%$ of the newborns of mothers in the poorest quintile were preterm, as compared to $12 \%$ in the wealthiest quintile) (data not shown) and consequently a threefold greater risk of the children dying from avoidable causes. The reduction of prematurity in this group thus becomes the most important primary prevention measure for controlling avoidable infant deaths 31 . Beyond the increase in prevalence observed in Brazil and in other countries $32,33,34,35$, there is no safe level of prematurity for infant survival. Other analyses in the 2004 cohort have shown that borderline preterm infants (34-36 weeks gestational age group) present a fivefold risk of dying in the neonatal period as compared to term newborns 36 , even though the present study did not show this phenomenon (probably due to the small number of avoidable deaths in this gestational age group). This risk persists over the course of the first year of life, and infant mortality is twice as high in borderline preterm infants as compared to term infants 36 .

However, knowledge on the prevention of preterm births is still very limited. Only two prenatal measures have proven preventive effectiveness: smoking cessation and use of progesterone in pregnant women with a history of preterm delivery prior to the current pregnancy 22 . A review published in 2009 showed that smoking cessation interventions during pregnancy decrease the risk of preterm births by $14 \%$ (relative risk $\mathrm{RR}=0.86$; 95\% confidence interval $-95 \% \mathrm{CI}$ : 0.74 0.98) 37. A meta-analysis of six randomized trials comparing progesterone and placebo in highrisk women (with a history of preterm births in previous pregnancies) showed a $35 \%$ reduction in preterm births (RR = 0.65; 95\%CI: 0.54-0.79) 38 . Evidence is limited on the effectiveness of screening for (and treatment of) asymptomatic urinary tract infection, although a meta-analysis of four observational studies indicated a reduction of preterm births among women without (compared to with) bacteriuria 39. Counseling for smoking cessation, identification of women with a history of preterm births, and screening for asymptomatic bacteriuria are all procedures recommended by the prenatal care program 40 , feasible for implementation in the primary health care system.

In the current study, 15 of the 29 avoidable deaths among children of mothers that smoked and six of the deaths among children of mothers with a history of preterm births were attributed to prematurity (data not shown). Although pregnant women are generally exposed to several risks si- multaneously, when one extrapolates the isolated protective effect of smoking cessation counseling and prescribing progesterone to mothers from the 2004 cohort, it would have been possible to prevent only five of the 39 deaths attributed to prematurity. Even among the nine deaths of children of mothers that failed to receive prenatal care $(n=73)$, the possibility of prevention would have been limited, because the child of the only mother that smoked was not preterm, and the eight mothers that did not smoke did not have a history of preterm births. Thus, only 30 of the 70 deaths classified as avoidable could have been prevented with the knowledge and resources currently available in our context.

Most of the children that died from avoidable causes had a 5-minute Apgar less than 7 and were not breastfed in the first 24 hours. In addition to the fact that these are independent risk factors for infant mortality 41,42 , their effect can also reflect residual confounding from prematurity.

One of this study's hypotheses was that the prenatal care provided in the public health system was associated with increased risk of dying from an avoidable cause 43 . This proved not to be the case. However, the actual quality of the individual prenatal care as expressed by the two variables number of prenatal visits and tetanus vaccination (indicative of compliance with the prenatal program guidelines) was a strong determinant of avoidable deaths. Evaluations of the quality of prenatal care in Pelotas $28,29,30$ at different moments have identified deficiencies in prenatal follow-up in the public system as compared to out-of-pocket prenatal care. In addition, previous analyses of the 2004 cohort showed that low income, low schooling, black skin color, and single motherhood are maternal characteristics that increase the likelihood of unequal access to screening for asymptomatic urinary tract infection during pregnancy 44 .

The association shown in the unadjusted analysis between delivery under the SUS and avoidable deaths (which disappeared in the multivariate model) probably reflects the effects of confounding variables, since more than $80 \%$ of the births in Pelotas are financed by the SUS 45 .

Finally, the message for health system administrators is that although it is necessary to understand more about the causality of preterm births in order to test new preventive measures, there is an urgent need to promote health professionals' adherence to the guidelines of the prenatal care program. Children of women in the two poorest income quintiles constitute the most vulnerable group for these causes of death. This should be the priority group of pregnant women for targeting these preventive measures. These women 
generally use the public health system or live in areas covered by it 46 , and are thus the natural target for measures by the health teams in the primary care system. Counseling for smoking cessation, screening of asymptomatic urinary tract infection, and identification of pregnant women with a history of preterm deliveries are simple procedures that could prevent part of the deaths resulting from prematurity. In addition, the prevention of congenital syphilis (identified as an important risk factor for neonatal mortality in other areas of Brazil 47 and which accounts for two of the deaths in the 2004 cohort) and education for the child's adequate sleep hygiene, counseling the mother to place the baby in dorsal decubitus (supine), could avoid an additional portion of early childhood deaths. Although small, these numbers could reduce the difference in the risk of dying between children from the extreme family income brackets.

\section{Resumo}

Os óbitos evitáveis têm sido utilizados como indicadores de qualidade da atenção à saúde. Este estudo teve como objetivo identificar os fatores associados aos óbitos evitáveis até os 4 anos de idade entre as crianças da Coorte de Nascimentos de Pelotas, Rio Grande do Sul, Brasil, de 2004. De 1o de janeiro de 2004 a 31 de dezembro de 2005, os óbitos foram monitorados diariamente, as causes, investigadas e classificadas conforme a evitabilidade. Após o primeiro ano, os óbitos foram monitorados por meio do Sistema de Informações sobre Mortalidade. Até os 4 anos, ocorreram 94 óbitos, sendo possível classificar 92, dos quais 70 seriam evitáveis. Baixa renda, menor número de consultas prénatais, pré-natal de pior qualidade, prematuridade, baixo Apgar no 5o minuto e não mamar nas primeiras 24 horas associaram-se a risco aumentado de morrer por cause evitável. Prematuridade estava presente em 39 óbitos, mas somente 5 desses teriam sido prevenidos por intervenções no pré-natal. Embora limitada, a adesão às normas do programa de atenção pré-natal, especialmente entre as mais pobres, ainda é a principal estratégia para a prevenção das mortes evitáveis na infância.

Mortalidade Neonatal; Mortalidade Infantil; Avaliação

\section{Contributors}

I. S. Santos conceived the study, planned the analysis, participated in the interpretation of the findings, and wrote the first version of the paper. N. C. J. Valle performed the statistical analyses. L. R. M. R. Gorgot, E. P. Albernaz, and A. Matijasevich analyzed and classified the deaths' avoidability. A. J. D. Barros, M. R. Domingues, D. C. Malta, and F. C. Barros participated in the interpretation of the findings and revision of the paper. All the authors contributed to the final version of the article.

\section{Acknowledgments}

This article is based on data from the 2004 Pelotas (Brazil) birth cohort study, conducted by the Graduate Studies Program in Epidemiology at the UFPel. The study is currently financed by the Wellcome Trust Initiative. Previous phases were financed by the World Health Organization, PRONEX, CNPq, Brazilian Ministry of Health (Ministério da Saúde), and Children's Pastoral Commision (Pastoral da Criança). 


\section{References}

1. Programa das Nações Unidas para o Desenvolvimento. Objetivos de desenvolvimento do milênio. http://www.pnud.org.br/odm (accessed on 03/ Mar/2010).

2. United Nations Children's Fund. Tracking progress in maternal, newborn \& child survival. The 2008 Report. New York: United Nations Children's Fund; 2008.

3. Ministério da Saúde. Saúde Brasil 2008: uma análise da situação de saúde. Brasília: Ministério da Saúde; 2009. (Série G. Estatística e Informação em Saúde).

4. Victora CG, Barros FC. Infant mortality due to perinatal causes in Brazil: trends, regional patterns and possible interventions. São Paulo Med J 2001; 119:33-42.

5. Rutstein DD, Berenberg W, Chalmers TC, Child 3rd CG, Fishman AP, Perrin EB. Measuring the quality of medical care. A clinical method. N Engl J Med 1976; 294:582-8.

6. Abreu DM, Cesar CC, Franca EB. Relação entre as causas de óbito evitáveis por atenção à saúde e a implementação do Sistema Único de Saúde no Brasil. Rev Panam Salud Pública 2007; 21:282-91.

7. Hadad S, França E, Uchôa E. Preventable infant mortality and quality of health care: maternal perception of the child's illness and treatment. Cad Saúde Pública 2002; 18:1519-27.

8. Hartz ZM, Champagne F, Leal MC, Contandriopoulos AP. Mortalidade infantil "evitável” em duas cidades do Nordeste do Brasil: indicador de qualidade do sistema local de saúde. Rev Saúde Pública 1996; 30:310-8.

9. World Health Organization. The world health report 2000. Health systems: improving performance. Geneva: World Health Organization; 2000.

10. Donabedian A. The quality of care. How can it be assessed? JAMA 1988; 260:1743-8.

11. Barros AJ, Santos IS, Matijasevich A, Araujo CL, Gigante DP, Menezes AM, et al. Methods used in the 1982, 1993, and 2004 birth cohort studies from Pelotas, Rio Grande do Sul State, Brazil, and a description of the socioeconomic conditions of participants' families. Cad Saúde Pública 2008; 24 Suppl 3:S371-80.

12. Puffer RR, Serrano CV. Patterns of mortality in childhood: the inter-American investigation of mortality in childhood. Washington DC: Pan American Health Organization; 1973.

13. World Health Organization. International statistical classification of diseases and related health problems. 10 th Revision. Geneva: World Health Organization; 1993.

14. Martin JA, Hamilton BE, Sutton PD, Ventura SJ, Menacker F, Munson ML. Births: final data for 2003. Natl Vital Stat Rep 2005; 54:1-116.

15. Fenton TR. A new growth chart for preterm babies: Babson and Benda's chart updated with recent data and a new format. BMC Pediatr 2003; 3:13.
16. Dubowitz LM, Dubowitz V, Goldberg C. Clinical assessment of gestational age in the newborn infant. J Pediatr 1970; 77:1-10.

17. Williams RL, Creasy RK, Cunningham GC, Hawes WE, Norris FD, Tashiro M. Fetal growth and perinatal viability in California. Obstet Gynecol 1982; 59:624-32.

18. Malta DC, Duarte EC, Almeida MF, Dias MAS, Morais Neto OL, Moura L, et al. Lista de causas de óbitos evitáveis por intervenções do Sistema Único de Saúde. Epidemiol Serv Saúde 2007; 16:233-44.

19. Adams SM, Good MW, Defranco GM. Sudden infant death syndrome. Am Fam Physician 2009; 79:870-4.

20. Barros AJ, Hirakata VN. Alternatives for logistic regression in cross-sectional studies: an empirical comparison of models that directly estimate the prevalence ratio. BMC Med Res Methodol 2003; 3:21.

21. Nantulya VM, Reich MR. Equity dimensions of road traffic injuries in low- and middle-income countries. Inj Control Saf Promot 2003; 10:13-20.

22. Barros FC, Bhutta ZA, Batra M, Hansen TN, Victora CG, Rubens CE. Global report on preterm birth and stillbirth (3 of 7): evidence for effectiveness of interventions. BMC Pregnancy Childbirth 2010; 10 Suppl 1:S3.

23. Weisz D, Gusmano MK, Rodwin VG, Neuberg LG. Population health and the health system: a comparative analysis of avoidable mortality in three nations and their world cities. Eur J Public Health 2008; 18:166-72.

24. Nolte E, McKee M. Measuring the health of nations: analysis of mortality amenable to health care. BMJ 2003; 327:1129.

25. Hollstein RD, Vega J, Carvajal Y. Desigualdades sociales y salud. Nivel socioeconómico y mortalidad infantil en Chile, 1985-1995. Rev Med Chil 1998; 126:333-40.

26. Tobias M, Jackson G. Avoidable mortality in New Zealand, 1981-97. Aust N Z J Public Health 2001; 25:12-20.

27. Tobias M, Yeh LC. How much does health care contribute to health inequality in New Zealand? Aust N Z J Public Health 2007; 31:207-10.

28. Cesar JA, Matijasevich A, Santos IS, Barros AJ, Dias-da-Costa JS, Barros FC, et al. The use of maternal and child health services in three population-based cohorts in Southern Brazil, 1982-2004. Cad Saúde Pública 2008; 24 Suppl 3:S427-36.

29. Santos IS, Baroni RC, Minotto I, Klumb AG. Critérios de escolha de postos de saúde para acompanhamento pré-natal em Pelotas, RS. Rev Saúde Pública 2000; 34:603-9.

30. Silveira DS, Santos IS, Costa JSD. Atenção pré-natal na rede básica: uma avaliação da estrutura e do processo. Cad Saúde Pública 2001; 17:131-9.

31. Victora CG. Intervenções para reduzir a mortalidade infantil pré-escolar e materna no Brasil. Rev Bras Epidemiol 2001; 4:63-9. 
32. Barros FC, Victora CG, Matijasevich A, Santos IS, Horta BL, Silveira MF, et al. Preterm births, low birth weight, and intrauterine growth restriction in three birth cohorts in Southern Brazil: 1982, 1993 and 2004. Cad Saúde Pública 2008; 24 Suppl 3:S390-8.

33. Davidoff MJ, Dias T, Damus K, Russell R, Bettegowda VR, Dolan S, et al. Changes in the gestational age distribution among U.S. singleton births: impact on rates of late preterm birth, 1992 to 2002. Semin Perinatol 2006; 30:8-15.

34. Langhoff-Roos J, Kesmodel U, Jacobsson B, Rasmussen S, Vogel I. Spontaneous preterm delivery in primiparous women at low risk in Denmark: population based study. BMJ 2006; 332:937-9.

35. Silveira MF, Santos IS, Barros AJ, Matijasevich A, Barros FC, Victora CG. Increase in preterm births in Brazil: review of population-based studies. Rev Saúde Pública 2008; 42:957-64.

36. Santos IS, Matijasevich A, Silveira MF, Sclowitz IK, Barros AJ, Victora CG, et al. Associated factors and consequences of late preterm births: results from the 2004 Pelotas birth cohort. Paediatr Perinat Epidemiol 2008; 22:350-9.

37. Lumley J, Chamberlain C, Dowswell T, Oliver S, Oakley L, Watson L. Interventions for promoting smoking cessation during pregnancy. Cochrane Database Syst Rev 2009; (3):CD001055.

38. Dodd JM, Flenady VJ, Cincotta R, Crowther CA. Progesterone for the prevention of preterm birth: a systematic review. Obstet Gynecol 2008; 112: 127-34.

39. Romero R, Oyarzun E, Mazor M, Sirtori M, Hobbins JC, Bracken M. Meta-analysis of the relationship between asymptomatic bacteriuria and preterm delivery/low birth weight. Obstet Gynecol 1989; 73:576-82.
40. Departamento de Ações Programáticas Estratégicas, Secretaria de Atenção à Saúde, Ministério da Saúde. Pré-natal e puerpério: atenção qualificada e humanizada: manual técnico. Brasília: Ministério da Saúde; 2005. (Caderno no. 5: Direitos Sexuais e Direitos Reprodutivos).

41. Casey BM, McIntire DD, Leveno KJ. The continuing value of the Apgar score for the assessment of newborn infants. N Engl J Med 2001; 344:467-71.

42. Edmond KM, Zandoh C, Quigley MA, AmengaEtego S, Owusu-Agyei S, Kirkwood BR. Delayed breastfeeding initiation increases risk of neonatal mortality. Pediatrics 2006; 117:e380-6.

43. Victora C, Matijasevich A, Silveira M, Santos I, Barros A, Barros F. Socio-economic and ethnic group inequities in antenatal care quality in the public and private sector in Brazil. Health Policy Plan 2010; 25:253-61.

44. Silveira MF, Barros AJ, Santos IS, Matijasevich A, Victora CG. Socioeconomic differentials in performing urinalysis during prenatal care. Rev Saúde Pública 2008; 42:389-95.

45. Barros AJ, Santos IS, Bertoldi AD. Can mothers rely on the Brazilian health system for their deliveries? An assessment of use of the public system and out-of-pocket expenditure in the 2004 Pelotas Birth Cohort Study, Brazil. BMC Health Serv Res 2008; 8:57.

46. Behague DP, Goncalves H, Dias-da-Costa J. Making medicine for the poor: primary health care interpretations in Pelotas, Brazil. Health Policy Plan 2002; 17:131-43.

47. Saraceni V, Guimarães MHFS, Theme Filha MM, Leal MC. Mortalidade perinatal por sífilis congênita: indicador da qualidade da atenção à mulher e à criança. Cad Saúde Pública 2005; 21:1244-50.

Submitted on 28/Apr/2010

Final version resubmitted on 08/Aug/2010

Approved on 01/Set/2010 